\title{
IMPLEMENTASI MEDIA PEMBELAJARAN POWER POINT PADA KONSEP REDUKSI-OKSIDASI TERHADAP PENINGKATAN HASIL BELAJAR SISWA KELAS X SMA NEGERI 6 AMBON
}

\author{
A. Belseran ${ }^{1 *}$, S. Unwakoly ${ }^{1}$, F. Al-Hamid ${ }^{1}$ \\ ${ }^{1}$ Departement of Chemistry-FKIP, Pattimura University Ambon \\ Corresponding author: A. Belseran \\ *agnesbelseran@gmail.com
}

\begin{abstract}
ABSTRAK. Telah dilakukan penelitian pembelajaran pada konsep reduksi-oksidasi yang bertujuan untuk mengetahui peningkatan hasil belajar siswa melalui penerapan media pembelajaran power point kelas $\mathrm{X}$ SMA Negeri 6 Ambon. Subjek dalam penelitian ini adalah siswa kelas X MIA1 SMA Negeri 6 Ambon semester genap Tahun Pelajaran 2018-2019. Pengumpulan data menggunakan teknik tes dan observasi belajar siswa. Dari hasil analisa data diperoleh bahwa hasil belajar siswa kelas X MIA1 telah mencapai kriteria ketuntasan minimal yaitu pada aspek kognif, afektif, psikomotor dengan nilai akhir yang diperoleh adalah kualifikasi sangat baik 3 siswa (14,09\%), kualifikasi baik 14 siswa $(66,66 \%)$, dan kualifikasi cukup 4 siswa $(19,05 \%)$. Data pencapaian $\mathrm{N}$-gain yang diperoleh yaitu 17 siswa $(80,95 \%)$ mencapai kategori gain tinggi dan 4 siswa $(19,05 \%)$ mencapai gain sedang. Hasil respon siswa terhadap pembelajaran menggunakan power point diperoleh presentase rata-rata sebesar $76,69 \%$ dengan kategori sangat baik. Oleh karena itu, dapat disimpulkan bahwa penerapan media pembelajaran power point memberikan hasil dan respon yang baik untuk hasil belajar siswa pada konsep reduksi-oksidasi dengan kriteria pencapaian n-gain yang diperoleh adalah 0,77 .
\end{abstract}

Kata Kunci : Power Point, Respon, Hasil Belajar, Reduksi-Oksidasi

\section{Pendahuluan}

Penggunaan teknologi dalam menunjang proses belajar mengajar di sekolah sangat penting. Salah satunya adalah dengan membuat media pembelajaran berbasis teknologi. Media pembelajaran merupakan perangkat alat bantu atau pelengkap yang digunakan oleh guru dalam rangka berkomunikasi dengan siswa. Pemakaian media pembelajaran dalam proses pembelajaran dapat membangkitkan keinginan dan minat yang baru, membangkitkan motivasi dan rangsangan belajar dan bahkan membawa pengaruh psikologis terhadap siswa, termasuk hasil belajarnya (Kaluku, 2016:1).

Masalah umum dalam pendidikan kimia adalah hasil belajar yang rendah. Rendahnya hasil belajar ini dipengaruhi banyak faktor. Salah satunya adalah siswa menganggap pelajaran kimia merupakan pelajaran yang sulit sehingga siswa merasa kurang mampu mempelajarinya. Kebanyakan konsep-konsep dalam ilmu kimia merupakan konsep atau materi yang abstrak dan kompleks sehingga untuk mengatasi hal tersebut, materi perlu ditunjukkan dalam bentuk yang lebih konkret, misalnya dengan percobaan atau media tertentu (Gusbandono dkk., 2013:102).

Berdasarkan observasi di SMA Negeri 6 Ambon, diperoleh data hasil belajar siswa yang tergolong rendah khususnya pada konsep reaksi reduksi-oksidasi. Data observasi yang diperoleh menunjukkan bahwa hanya $40 \%$ siswa yang mencapai KKM dan sisanya $60 \%$ siswa tidak mencapai KKM yaitu dengan nilai $<65$. Hal ini disebabkan karena siswa kesulitan dalam memahami konsep reaksi reduksi-oksidasi. Salah satu konsep yaitu dalam menentukan bilangan oksidasi atom dalam molekul atau ion. Sementara itu hasil wawancara dengan guru mata pelajaran menunjukkan bahwa guru menggunakan metode pembelajaran yang interaktif dalam proses pembelajaran kimia, namun masih ada kekurangan dalam proses pembelajaran yang menyebabkan prestasi belajar siswa masih rendah, yaitu kurangnya penggunaan media yang sebenarnya sangat dibutuhkan dalam proses pembelajaran.

Disamping pemilihan metode pembelajaran yang tepat, penggunaan media pembelajaran yang inovatif dan sesuai dengan tujuan pembelajaran, materi, keadaan siswa serta sarana yang tersedia juga dapat mendukung terciptanya pembelajaran yang menarik, yang pada akhirnya akan meningkatkan prestasi belajar siswa. Salah satu 
media yang dapat digunakan sebagai media pembelajaran adalah power point. Microsoft Power Point merupakan sebuah software yang dirancang khusus untuk membuat slide presentasi (Suarna, 2008:9) dan merupakan salah satu program berbasis multi media. Microsoft Power point digunakan untuk membuat dokumen presentasi dengan cepat dan mudah (Yulius, 2010:189). Program ini dirancang khusus untuk menyampaikan presentasi, baik yang diselenggarakan oleh perusahaan, pemerintahan, pendidikan, maupun perorangan, dengan berbagai fitur menu yang mampu menjadikannya sebagai media komunikasi yang menarik. Beberapa hal yang menjadikan media ini menarik untuk digunakan sebagai alat presentasi adalah berbagai kemampuan pengolahan teks, warna, gambar, suara, film, animasi, bahkan link ke internet yang bisa diolah sendiri sesuai kreatifitas penggunanya. Penggunaan program ini pun memiliki kelebihan antara lain: penyajiannya menarik karena ada permainan warna, huruf, suara, film, animasi, bahkan link ke jaringan internet, lebih merangsang anak untuk mengetahui lebih jauh informasi tentang bahan ajar yang tersaji, pesan informasi secara interaktif lebih mudah dipahami peserta didik, tenaga pendidik tidak perlu banyak menerangkan bahan ajar yang sedang disajikan, dapat diperbanyak sesuai kebutuhan, dan dapat dipakai secara berulang, dapat disimpan dalam bentuk CD/flashdisk, sehingga praktis untuk dibawa kemana-mana (Sofyanti, 2012: 3-4). Penelitian ini menggunakan media pembelajaran power point pada konsep reaksi reduksi-oksidasi dengan tujuan dapat meningkatkan hasil belajar siswa kelas X SMA Negeri 6 Ambon

\section{Metode}

\section{a. Penelitian Tipe Penelitian}

Tipe penelitian yang digunakan dalam penelitian ini adalah penelitian deskriptif kuantitatif. Dalam penelitian ini akan mendeskripsikan hasil belajar siswa pada konsep reduksi-oksidasi dengan menggunakan media pembelajaran power point. Desain Penelitian ini menggunakan rancangan penelitian pre-eksperimen, yaitu one group pretest-postt design. Dengan rancangan desain penelitian yang digunakan sebagai berikut :

$$
\begin{array}{l|c|} 
& \mathrm{O}_{1} \times \mathrm{O}_{2} \\
\text { Dimana : } & \mathrm{O}_{1}=\text { nilai pretest } \\
& \begin{array}{l}
\mathrm{X}=\text { penerapan media pembelajaran power point } \\
\mathrm{O}_{2}=\text { nilai posttest }
\end{array} \\
\text { (Sugiyono, 2010:112) }
\end{array}
$$

\section{b. Populasi dan Subjek Penelitian}

Populasi penelitian ini adalah siswa SMA NEGERI 6 AMBON kelas X. Pengambilan subjek pada penelitian ini adalah siswa kelas X MIA1 dengan jumlah siswa 21 orang. Pengambilan subjek penelitian menggunakan teknik simple random sampling.

\section{c. Tempat dan Waktu Penelitian}

Penelitian ini dilaksanakan di SMA NEGERI 6 AMBON pada semester genap tahun ajaran 2018/2019.

\section{d. Variabel Penelitian}

Variabel yang digunakan adalah variabel tunggal, yakni hasil belajar siswa pada konsep reduksi-oksidasi dengan menerapkan media pembelajaran power point.

\section{e. Instrumen Penelitian}

Instrumen yang digunakan dalam penelitian ini adalah:

1. Instrumen tes berupa tes awal, dan tes akhir dalam bentuk PG dan essay.

2. Instrument non tes berupa lembar pengamatan afektif, lembar pengamatan psikomotor, dan angket respon siswa.

3. LKPD (Lembar Kerja Peserta Didik)

\section{f. Teknik Pengumpulan Data}

Untuk memperoleh data yang akurat dalam penelitian ini dilakukan beberapa teknik pengumpulan data sebagai berikut: 1) Teknik tes. Tes dilakukan sebelum dan sesudah proses belajar mengajar yaitu berupa tes awal dan tes akhir. 2) Teknik non tes.

a) Pengamatan atau Observasi. Pengamatan dilakukan untuk mengumpulkan data penelitian yang berkaitan dengan aktivitas siswa selama mengikuti proses pembelajaran. Data yang dikumpulkan dan diobservasi untuk pengamatan afektif dan psikomotor.

b) Angket respon siswa. Angket ini digunakan untuk mengetahui respon siswa terhadap pembelajaran kimia menggunakan media pembelajaran power point. Dalam menganalisis data yang berasal dari angket bergradasi 
atau berperingkat satu sampai empat, peneliti menyimpulkan makna setiap alternatif sebagai berikut: 1)“Sangat setuju" menunjukkan gradasi paling tinggi, diberi nilai 4. 2)“Setuju”, diberi nilai 3.3) "Kurang setuju”, diberi nilai 2. 1)“Tidak setuju", diberi nilai 1. 3) Lembar Kerja Peseta Didik (LKPD). LKPD digunakan untuk membantu peneliti dalam mengevaluasi hal-hal yang berhubungan dengan penguasaan materi (aspek kognitif) serta memberikan penilaian kepada siswa selama proses belajar mengajar.

\section{g. Teknik Analisis Data}

Teknik analisis data yang digunakan adalah teknik analisis deskriptif, yaitu teknik analisis untuk mengetahui hasil belajar kognitif siswa.

a). Hasil Belajar Kognitif Produk. Hasil belajar kognitif produk dapat diperoleh dengan menggunakan rumus sebagai berikut:

Skor Pencapaian $=\frac{\text { Jumlah skor yang diperoleh }}{\text { skor total }} \times 100 \%$

Kemudian dikonversikan dengan menggunakan Tabel tingkat penguasaan kompetensi dan kualifikasinya. Ini dapat dilihat pada tabel 3.2 berikut ini:

Tabel 1. Konversi Nilai KKM SMA NEGERI 6 AMBON

\begin{tabular}{cc}
\hline Tingkat Penguasaan & Kualifikasi \\
\hline $86-100$ & Sangat Baik \\
$76-85$ & Baik \\
$65-75$ & Cukup \\
$<65$ & Kurang / Gagal \\
\hline
\end{tabular}

(Sumber : KKM SMA NEGERI 6 Ambon)

Selanjutnya data yang diperoleh dari hasil tes kemampuan awal dan tes kemampuan akhir siswa dianalisis untuk mendapatkan skor peningkatan (gain) analisis dengan menggunakan $N$-gain (Normalized gain) bertujuan untuk mengetahui besarnya peningkatan kemampuan pemahaman atau penguasaan konsep siswa setelah pembelajaran dilakukan. Peningkatan dihitung dengan rumus sebagai berikut:

$$
N \text {-gain }=\frac{\text { skor tes akhir-skor tes awal }}{\text { skor maksimum-skor tes awal }} \quad \text { Nuraini, 2013: 33) }
$$

b). Lembar Penilaian Afektif dan Psikomotor. Untuk penilaian afektif dan psikomotor siswa, digunakan penskoran dengan rumus:

SkorPencapaian $=\frac{\text { jumla skor yang diperoleh }}{\text { jum skor maksimum }} \times 100$ (Sudijono, 2005: 318)

c). Angket Respon Siswa

Besarnya respon siswa dapat dihitung dengan rumus berikut:

Persentase respon siswa $=\frac{\text { jum skor respon siswa }}{\text { skor maksimal }} \times 100$ (Riduwan, 2008:89)

Kemudian dapat dikategorikan berdasarkan tingkat respon siswa seperti pada tabel 2 dibawah ini.

Tabel 2. Kategori Respon Siswa

\begin{tabular}{cc}
\hline Persentase Angka (\%) & Kategori \\
\hline $76-100$ & Sangat baik \\
$51-75$ & Baik \\
$26-50$ & Cukup \\
$0-25$ & Kurang \\
\hline
\end{tabular}

(Riduwan, 2008: 89) 
d). LKPD (Lembar Kerja Peserta Didik)

Total skor pencapaian untuk aspek kognitif pada LKPD dapat diperoleh dengan menggunakan rumus sebagai berikut:

Skor Pencapaian $=\frac{\text { skor yang diperoleh }}{\text { skor maksimal }} \times \mathbf{1 0 0}($ Ratumanan, 2003: 106).

\section{Hasil Penelitian}

Berdasarkan penelitian yang dilakukan, berikut ini akan disajikan deskripsi hasil belajar siswa kelas X MIA1 SMA Negeri 6 Ambon pada konsep reduksi- oksidasi sebagai berikut:

\section{a. Deskripsi Hasil Tes Awal Siswa}

Data kualifikasi Hasil Tes Awal Siswa ditunjukan pada Tabel 3.

\begin{tabular}{cccc}
\hline Nilai & Frekuensi & $\begin{array}{c}\text { Frekuensi Relatif } \\
(\mathbf{\%})\end{array}$ & Kualifikasi \\
\hline $86-100$ & - & - & Sangat baik \\
$76-85$ & - & - & Baik \\
$65-75$ & - & - & Cukup \\
$<65$ & 21 & 100 & Kurang/Gagal \\
\hline Jumlah & 21 & 100 & \\
\hline
\end{tabular}

Berdasarkan Tabel 3, hasil tes awal yang diikuti oleh 21 siswa menunjukkan bahwa 100\% siswa gagal atau semua siswa tidak maksimal dalam menjawab soal tes awal pada konsep reduksi-oksidasi. Hal ini disebabkan karena konsep reduksi-oksidasi belum pernah diajarkan kepada siswa sehingga pengetahuan awal siswa terhadap konsep reduksi-oksidasi masih minim dan siswa tidak memiliki kesiapan yang cukup sebelum mengikuti proses pembelajaran. Nilai tes awal tertinggi adalah 28,33 dan terendah adalah nol. Hal ini menunjukkan bahwa secara keseluruhan siswa masih memiliki pengetahuan yang minim tentang konsep reduksi-oksidasi.

\section{b. Deskripsi Hasil Belajar Selama Proses Pembelajaran}

Selama proses pembelajaran berlangsung kemampuan siswa dinilai dalam tiga aspek yaitu aspek kognitif (pengetahuan), aspek afektif (sikap), dan aspek psikomotor (keterampilan).

\section{c. Deskripsi Hasil Belajar Siswa Pada Tes Akhir}

Tes akhir adalah tes yang diberikan kepada siswa setelah proses pembelajaran selesai. Menurut Harjanto (2010 : 285), tujuan dilaksanakan tes akhir adalah untuk mengetahui tingkat penguasaan siswa terhadap indikatorindikator pembelajaran yang telah diberikan. Data kualifikasi hasil belajar siswa pada tes akhir ditunjukkan pada Tabel 4.

\begin{tabular}{cccc}
\hline Nilai & Frekuensi & $\begin{array}{c}\text { Frekuensi Relatif } \\
(\mathbf{\%})\end{array}$ & Kualifikasi \\
\hline $86-100$ & 3 & 14,29 & Sangat baik \\
$76-85$ & 14 & 66,66 & Baik \\
$65-75$ & 4 & 19,05 & Cukup \\
$<65$ & - & - & Kurang/Gagal \\
\hline Jumlah & 21 & 100 & \\
\hline
\end{tabular}

Berdasarkan Tabel 4 menunjukkan bahwa kemampuan siswa pada tes akhir adalah 3 siswa berada pada kualifikasi sangat baik. Hal ini dikarenakan dalam proses pembelajaran siswa sangat serius dan termotivasi dalam belajar sehingga dalam penyelesaian soal dapat mengerjakan dengan benar. Sedangkan 14 siswa berada pada kualifikasi baik dikarenakan siswa berhasil menyelesaikan soal setiap indikator tetapi ada beberapa penyelesaian yang dikerjakan kurang tepat dan 4 siswa berada pada kualifikasi cukup dikarenakan dalam proses penyelesaian soal seperti menentukan reduktor dan oksidator kurang tepat, menentukkan nama senyawa kurang tepat, serta menentukkan bilangan oksidasi suatu senyawa tidak sampai hasil akhir. Hal ini dikarenakan dalam proses pembelajaran siswa kurang serius dan kurang termotivasi dalam belajar. 
Jika dilihat hasil tes akhir daripada siswa, terjadi peningkatan hasil belajar dari nilai tes awal. Dengan membandingkan nilai tes awal dengan nilai tes akhir, maka dapat disimpulkan bahwa semua siswa dapat mencapai KKM setelah mengikuti proses pembelajaran menggunakan media pembelajaran power point. Dengan demikian tujuan penerapan media pembelajaran power point dapat dikatakan telah tercapai, karena nilai akhir dari seluruh siswa lebih tinggi daripada nilai tes awal.

\section{d. Deskripsi Data N-Gain}

Kategori nilai N-gain dapat ditunjukkan pada Tabel 5

\begin{tabular}{cccc}
\hline Interval & Frekuensi & $\begin{array}{c}\text { Frekuensi Relatif } \\
(\mathbf{\%})\end{array}$ & Kategori \\
\hline $\mathrm{g}>0,7$ & 17 & 80,95 & Tinggi \\
$0,3 \leq \mathrm{g} \leq 0,7$ & 4 & 19,05 & Sedang \\
$\mathrm{g}<0,3$ & - & - & Rendah \\
\hline Jumlah & 21 & 100 & \\
\hline
\end{tabular}

\section{e. Deskripsi Angket Respon Siswa}

Setelah proses pembelajaran dengan menggunakan power point dilaksanakan, selanjutnya siswa diberikan angket berupa respon atau tanggapan siswa terhadap penggunaan power point pada pembelajaran. Persentase rata-rata respon siswa terhadap penggunaan power point dapat ditunjukkan pada Tabel 5.

\begin{tabular}{lll}
\hline Persentase angka (\%) & Rata-rata & Kategori \\
\hline $76-100$ & 76,69 & Sangat baik \\
$51-75$ & - & Baik \\
$26-50$ & - & Cukup \\
\hline $0-25$ & - & Kurang \\
\hline
\end{tabular}

\section{Kesimpulan}

Hasil penelitian disimpulkan bahwa penggunaan power point pada konsep reduksi-oksidasi memberikan respon dan hasil yang baik pada hasil belajar siswa kelas X MIA1 SMA Negeri 6 Ambon. Hal ini ditunjukkan dengan peningkatan hasil belajar siswa sebelum dan sesudah proses pembelajaran. Dimana pada tes awal 21 siswa (100\%) memperoleh kualifikasi tidak mencapai KKM, sedangkan pada tes akhir 3 siswa (14,29\%) memperoleh kualifikasi sangat baik, 14 siswa (66,66\%) memperoleh kualifikasi baik, dan 4 siswa (19,05\%) memperoleh kualifikasi cukup. Selain itu, respon siswa terhadap pembelajaran yang dilakukan dengan menggunakan power point sebesar $76,69 \%$ dengan kategori sangat baik, dan juga kriteria pencapaian $N$-gain yang diperoleh adalah 0,77 .

\section{Daftar Pustaka}

Arisusanti, Gusbandono, T., Sukardjo, J.S., \& Utomo, S.B. (2013). Pengaruh Metode Pembelajaran Kooperatif Student Team Achievement Division (STAD)Dilengkapi Media Animasi Macromedia Flash Dan Plastisin Terhadap Prestasi Belajar Siswa Pada Pokok Bahasan Ikatan Kimia Kelas X Semester 1 SMA Negeri 1 Sambung macan Tahun Pelajaran 2012/2013. Program Studi Pendidikan Kimia, PMIPA, FKIP, UNS, Surakarta Indonesia. Jurnal Pendidkan Kimia (JPK). Vol.2, No.4.ISSN: 23379995. 102-109.

Harjanto. (2010). Perencanaan Pengajaran. Jakarta : Rineka Cipta

Kaluku, A. (2016). Aplikasi Media Pembelajaran Macromedia Flash Pada Konsep Kelarutan Dan Hasil Kali Kelarutan Terhadap Hasil Belajar Siswa Kelas XI Madrasah Aliyah Al-Mabrur Ambon. Skripsi.

Nuraini, R. (2013). Penerapan Contextual Teaching Learning (CTL) Untuk Meningkatkan Hasil Belajar Siswa Pada Standar Kompetensi Memupuk. Universitas Pendidikan Indonesia. repository.upi.edu.23-34

Ratumanan, T.G. (2003). Belajar dan Pembelajaran. Surabaya: Unesa University Press, 106.

Riduwan. (2008). Belajar Mudah Penelitian Untuk Guru-Karyawan dan PenelitiPemula. Bandung: Alfabeta,89 
Sofyanti, Y. (2012). Pengaruh Penggunaan Media Pembelajaran PowerPoint berbasis Goggle Translate Terhadap Pemahaman Kosakata Bahasa Inggris. (Penelitian Quasi Eksperimen terhadap Mahasiswa Amik Garut Tahun Ajaran2011/2012) Artikel penelitian. 1-10.

Suarna, N. (2008). Pedoman panduan praktikum: Microsoft office powerpoint. Bandung: C.V YramaWidya. Sudijono, A. (2005). Pengantar Evaluasi Pendidikan. Jakarta: Paja Grafindo Persada

Sugiyono. (2010). Metode penelitian pendidikan. Bandung: Alfabeta

Yulius, O. (2010). Akses Cepat Menguasai Microsoft Office 2010. Jakarta: Jalur Masmedia 